\title{
Participatory Epizootiology Research of Settled Pastoralists in Igangan Grazing Reserve, Southern Guinea Agro-Pastoral Zone, Oyo State, Nigeria: First Report
}

BABALOBI, 0. 0

Department of Public Health and Preventive Medicine, Faculty of Veterinary Medicine, University of Ibadan, Nigeria Email: tayobabalobi@yahoo.com; oo.babalobi@mail.ui.edu.ng_Tel: +234-805-530-1991; +234-708-551-9119

\section{SUMMARY}

A Participatory Epizootiology Research of a Fulani agropastoralist settlement scheme, the Igangan Grazing Reserve, Oyo State, Southwest Nigeria between 2007 and date, is ongoing under a University of Ibadan, Nigeria Senate Research Grant Program. The objective is to identify and rank the expressed epizootiological and livestock health problems, as well as the socio-economic needs related to livestock-keeping, of the pastoralists in the study area. After obtaining approval from the reserve authorities (the Oyo State Government), an initial field assessment, two interactive focus group discussions meetings and a second physical field visit took place between December 2007 and June 2009. Respondents included the traditional Fulani grazing reserve head, who has been a settler on the reserve for forty (40) years, his educated first son and heir apparent, as well as fifteen (15) other settler leaders/elders. There were between twenty-seven (27) and forty-seven (47) permanent settlers, depending on the season of the year, with cattle holding of $50-600$ per household. Settlers were mainly Fulani pastoralists. Problems highlighted by settlers included inadequate space for settler families, crop farmer/pastoralist skirmishes, and non-availability of feed all year round and absence of veterinary / animal care services. Expressed needs were for basic veterinary training in animal care (and not just drug usage), disease prevention and management practices and veterinary extension education. Four (4) major reserve diseases identified were Charbo (Foot-andMouth Disease), Samore (Trypanosomosis), Eheren/Unto (Contagious Bovine Pleuro-pneumonia) and Wolah (Skin eruptions).

KEY WORDS: Participatory epizootiology, Settled pastoralists, Grazing reserve, Oyo state, Nigeria.

\section{INTRODUCTION}

Participatory Epizootiology, referred to by others as Participatory Epidemiology, (PE) is the use of participatory approaches and methods, involving the community based livestock keepers, to improve the understanding of their animal diseases and production problems, and to design appropriate veterinary intervention and other action plans for these problems. Over time, participatory methods have attracted increasing interest from veterinarians and are now used by a wide range of organizations. Veterinarians in Africa have been using the participatory approaches and methods since the 1980's. This has led to the adoption of the concept by the African Union's InterAfrican Bureau for Animal Resources (OAU/IBAR) under the Community-based Animal Health and Participatory Epidemiology (CAPE) Unit of the Pan African Programme for the Control of Epizootics (PACE) Nairobi, Kenya (Catley and Mariner 2002).

Pastoralism is a (ruminant) animal-rearing livelihood activity practiced in a variety of ways as a response to the dictates of the immediate environment and available resources. Animals are grazed over varying distances depending on availability of fodder, water, etc in a livestock livelihood pastoral production system known as Transhumance Pastoralism. Transhumant Pastoralists are the main livestock producers in Nigeria and are found as nomadic, semi-settled and settled livestock producers in different ecological and socioeconomic settings of Nigeria.

There have been several reports of nonsustainability of many western introduced livestock development projects. These efforts have largely failed due to the noninvolvement/participation of the target beneficiaries in the design appraisal, implementation, monitoring and evaluation of such project, leaving the traditional production 
system only slightly improved over time with Nigeria's animal protein deficit worsen over time (Nuru 1982, David-West 1982, 1989, Awogbade and Hassan 1987, Bincah 1987, Oluokun 1992, Babalobi and Esuruoso 1999, 2000). One of such failed non sustained developmental approach is the Grazing Reserve (GR) Pastoralist Settlement Scheme, which was early studied in another part of Nigeria (Falobi 1998).

The Grazing Reserve Scheme, the most sustained effort at pastoral development in Nigeria, arose from a 1949-1954 World Bank review of Nigeria's Livestock sector (Suleiman 1988), which recommended the establishment of Grazing Reverse in major cattle producing areas to “... stabilize the pastoral production system... and to utilize an area to demonstrate to the pastoralist that a sustained high level of development can be achieved by combining free range management with modern management practices" (Awogbade and Famoriyo 1982).

The first GR was established in 1964 as the Rumar-Kukar-Jangari GR in the present Katsina State, eight more have been established by the Federal Government under the First (19761983) and Second (1987 -1995) Livestock Development Programme (1985a; 1985b, SLDP 1988), while the 1988 Agricultural Policy specifies that a minimum of the country's land area be legally acquired and constituted into GRs for lease to grazers (Anon, 1988). Various state governments have thus designated certain land areas for GRs, one of which is the Igangan Grazing Reserve, Ibarapa North Local Government Area in the Southern Guinea Zone, Oyo State, Nigeria.

This project was embarked upon to apply PE principles to assess the grazing reserve livestock production development approach to integrating pastoralists into the regional ecological and socio-economic settings of South West Nigeria. The project also identified and rank the expressed epizootiological and livestock health problems, as well as the socio-economic needs related to livestock-keeping, of the pastoralists in the study area.

\section{MATERIALS AND METHODS}

After obtaining approval from the reserve authorities, the Oyo state government, an initial field assessment took place in December 2007, following contacts with the traditional Fulani grazing reserve head, who has been a settler on the reserve for about forty (40) years. The purpose was to gather basic information on the grazing reserve settlement and familiarize the researcher with the topography, livestock situation and human community through an interactive session with the settler leaders.

A semi-structured interview with the reserve head in company of his educated first son and heir apparent as key informant, (as well as fifteen (15) other settler leaders/elders), was also conducted in December 2007, to get acquainted with the history and the present situation of the settlement, the settlement problems, the settlers' expressed need and the animal and human health situation of the reserve. A second interactive session took place in January 2008. It involved a veterinary extension education session of the Igangan Reserve pastoralists through the video screening and translation of the United States Department of Agriculture USDA/APHIS Animal Health Emergency Management Training Compact Disk (CD) on Foreign Animal Diseases and AU-IBAR Community Animal Health Workers Scheme CD. As a result of the above interactive sessions, the settlers requested for a basic Community Based Animal Health training and this was conducted over four weekends in February 2008 at the Department of Veterinary Public Health and Preventive Medicine, University of Ibadan, Nigeria. The educated first son of the reserve leader was nominated by the leadership of the reserve to attend the training. A follow-up field visit took place in June 2009, and involved physical exploratory visit to about $25 \%$ of the reserve and an interactive discussion with two other children of the reserve head.

\section{RESULTS}

The Igangan Grazing Reserve had been a forest reserve before it was converted into a grazing reserve. Settler families (households) in the reserve vary annually from between twentyseven (27) permanent settlers to up to fortyseven (47) households, depending on the season of the year. As of December 2007, there were about thirty six (36) settler families on the reserve with cattle holding of 50-600 per family. Twenty-seven (27) of these were permanent 
settlers that have spent up to forty years in the reserve. Settlers were mainly Fulani pastoralists even though indigenous non-Fulani pastoralists were attempting to encroach. However, between $10-20$ nomadic pastoralist families (known as Bororo), annually come to temporarily graze in the reserve between December to May (which mark the end of harvest time/commencement of dry season, and commencement of rainy season respectively). Thus, livestock population at the reserve peaks between January and April yearly.

Highlighted settler problems include inadequate space for settler families, crop farmer/pastoralist skirmishes over grazing sites, especially during rainy season, leading to semi-migration to nearby grazing areas, non-availability of feed all year round and absence of veterinary/ animal care services in the reserve. The major expressed need was for basic veterinary training in animal care (and not just drug usage), disease prevention and management practices and veterinary extension education. Other expressed needs include construction of a dam, provision of veterinary clinic, cattle market, nomadic education schools for their children and potable drinking water.

Thus the settlers emphasized that their major expressed need was for basic veterinary training in animal care (and not just drug usage), disease prevention and management practices and veterinary extension education. This led to a Community Based Animal Health training of settler nominated pastoralist-the educated first born of the reserve head that holds a Diploma in Mass Communication.

The four (4) major diseases identified by consensus of the pastoral settlers during the semi-structured interview with the reserve head, his educated first son/heir apparent, fifteen (15) other settler leaders/elders and the other interactive sessions were Charbo (Foot-andMouth Disease), Samore (Trypanosomosis), Eheren/Unto (Contagious Bovine Pleuro pneumonia) and Wolah (Skin eruptions). In addition to the pastoral settlers disease occurrence perception, a suspected case of Contagious Bovine Pleuropneumonia (CBPP) around the pastoralist settlement has been earlier confirmed by gross and histopathological examination of two pieces of lungs submitted for post mortem analysis at the Pathology Unit, Department of Veterinary Pathology, Faculty of Veterinary Medicine, University of Ibadan by the Principal Veterinary Officer of the nearby Eruwa Veterinary Field Station of the Faculty of Veterinary Medicine University of Ibadan on 15th August 2007. The lung sample was from diseased cattle brought to his attention by a Pastoralist.

\section{DISCUSSION}

Community knowledge related to animal health has been termed existing veterinary knowledge. Existing veterinary knowledge is largely based on clinical, gross pathological and epidemiological observations, its specificity is limited. The reliability of the community's diagnosis is probably comparable to clinician's appraisals in the absence of laboratory support. However, the two types of information are not equivalent. The community often detects disease problems long before, and more frequently than, clinicians (FAO, 2001). Over the last few decades, collection of existing veterinary knowledge through surveys became an important method for the identification and prioritisation of animal health problems within communities (McCorkle and Mathias-Mundy 1992)

The role of participatory techniques in disease surveillance is primarily to ensure that surveillance is sensitive and timely; that a high percentage of significant field events are detected and investigated. In the case of disease eradication, participatory epidemiology can also be used as a sensitive tool to confirm the absence of clinical disease. Participatory epidemiology is a decision or action-oriented intelligence gathering activity. Qualitative Participatory Epidemiology is usually complemented by modern scientific Quantitative Research. Qualitative research is based on the collection of observations, historical reports and opinions of informants as well as the direct observations of the researcher. Often, expert or key informants are used. For the most part, data is collected and recorded as non-numeric, non-categorical testimony, explanations and interpretations of the participants. During the process of qualitative reconnaissance, the data can be transformed into quantitative information at several points, if the investigator so desires (FAO, 
2001). As earlier reported above, pastoralists in the reserve have earlier identified infected lung samples suspected to be CBPP infected and called the attention of a veterinary practitioner, who brought the samples for post mortem analysis and confirmation by gross and histopathological examination. This is an example of the desired complementary roles of traditional Qualitative Participatory Epidemiology Research and Modern scientific Quantitative Epidemiology.

The advantage of the application of Participatory Research approach to settled pastoralists in a remote rural Grazing Reserve like Igangan is that it is cheap, has a low capital base, involves the traditional settler beneficiaries in identification of enzootic animal problems and gives opportunity for a Community Based Animal Health training of nominated settler. Beyond more accurate epidemiological analysis, the inclusion of livestock owner information in project design and disease control strategies will insure the appropriateness of animal health interventions and lead to better acceptance of disease control interventions by the animalowning public (FAO, 2001).

Other advantages of Participatory Methods in Epidemiological Studies include:

i. Participatory Research is often the only way of gathering data from certain areas, particularly remote or strife-torn areas. It is usually cheaper and more feasible than fullscale randomised surveys; thus often an attractive option for poorly-resourced veterinary services.

ii. Results are usually available very rapidly.

iii. It is more flexible and ably adapt to new issues uncovered during the appraisal.

iv. It is an effective method for the design of more conventional studies through better identification of the breadth, depth and priority of issues that may merit quantitative study

v. Participatory methods build on what local people already know; enables them to use their own knowledge and skills in disease surveillance and control.

vi. Participation is a tool for empowerment, particularly of the poor and of rural women.

The main disadvantage is the migratory pattern of settlers which affects effective year-round monitoring and surveillance of enzootic disease, may also lead to transboundary transmission of infectious diseases due to its migratory features as practiced by up to twenty (20) out of the forty seven (47) settlers in the reserve

\section{CONCLUSION}

The project is ongoing. As a follow-up to the initial semi-structured interview conducted with the reserve head in company of his educated first son and heir apparent, (and fifteen (15) other available settler leaders/elders), another more comprehensive one day community dialogue workshop is to be organized for other key members of the community such as (other) local chiefs, civil administration, carefully chosen cattle camp leaders, livestock owners, and women's leaders. The workshop will use participatory methods to further demonstrate the participatory epizootiology research concept and goals to participants, and to give them opportunity to corporately express epizootiological problems and the socioeconomic needs related to livestock-keeping of the pastoralists in the study area.

In addition after the workshop, a participatory baseline research survey of the reserve through physical data collection will be conducted to obtain baseline data against which future evaluations can be measured; using participatory rural appraisal techniques such as transect walks, group discussions, brainstorming, ranking exercises, participatory mapping and Geo-Informatics (GIS and GPS) tools. Information will be gathered on community structures, livestock numbers, management methods, movements, and knowledge of diseases and treatments. The participatory methods to be used allow the priorities of the community to be expressed, their extensive knowledge of livestock husbandry and diseases to be highlighted and lay the basis for all community members to contribute to programme development.

\section{ACKNOWLEDGEMENT}

The ongoing project is funded by a University of Ibadan Senate Research Grant Number SRG/FVM/2006/9A, Category A: Individual Research titled 'Participatory Epizootiology of the Igangan Grazing Reserve in Ibarapa Agro- 
Pastoral zone of Southwest Nigeria.

\section{REFERENCES}

ANON. (1988): The agricultural policy for Nigeria. Federal Ministry of Agriculture and Natural Resources, Abuja Nigeria.

AWOGBADE M. O. and FAMORIYO S. (1982): Nomadic land use and beef production in Nigeria. In Osinowo A.O. et al (eds.): Beef Production in Nigeria. Pro. Nat. Conf. Beef. Prod. Nigeria. 427- 454.

AWOGBADE M. O. and HASSAN U.A (1987): Prospects and problems of settlement schemes for nomadic Fulani in Nigeria. In Dafwang I.I et al (eds.): Livestock Extension Services and Animal Production in Nigeria. Pro. 1987 Livestock. Vet. Conf. AERLS \& NAPRI. $311-325$.

BABALOBI O. O. and ESURUOSO G.O. (1999): Grazing reserves and development of traditional pastoralism in Nigeria: progress and prospects. Tropical Veterinarian. 17:149-155.

BABALOBI O. O. and ESURUOSO G. O. (2000): Epizootiology of pastoralism in Nigeria. Proceedings of the Ninth International Symposium on Veterinary Epidemiology and Economics. ISVEE9, Colorado, USA. $6^{\text {th }}-11^{\text {th }}$ August 2000. 221-223.

BINCAH J.N. (1987): The constraints of livestock production in Nigeria: The role of the National Livestock Projects Department. In Dafwang I.I et al (eds.): Livestock Extension Services and Animal Production in Nigeria. Pro 1987 Livestock Vet. Conf AERLS \& NAPRI. 139-143.

CATLEY A. and MARINER J. C., (2002): Where there is no data. Participatory approaches to veterinary epidemiology in the pastoral areas of the Horn of Africa. International Institute for Environment and Development, Drylands Program. Issue paper No. 110.

DAVID-WEST K.B. (1982): Government activities in the beef industry. In Osinowo A.O et al (eds.): Beef Production in Nigeria. Pro. Nat. Conf. Beef. Prod. Nigeria. 4-7.

DAVID-WEST K.B. (1989): Strategies for improving livestock production in Nigeria Original essay submitted in partial fulfillment of requirements for award of the Membership of the National Institute (mni).

FAO (2001): Corporate Document Repository. Manual on Participatory Epidemiology. http://www.fao.org/DOCREP/003/X8833E/X8833E00.htm

FALOBI O. O. (1998): Epizootiology and the use of a Grazing Reserve for the Development of Pastoralism in Nigeria. A PhD thesis submitted to the Department of Veterinary Public Health and Preventive Medicine, Faculty of Veterinary Medicine, University of Ibadan, Nigeria. 145.

MCCORKLE, C.M. and MATHIAS-MUNDY, E. (1992). Ethnoveterinary medicine in Africa. Africa 62 (1), 59-93.

NIGERIA. (1985a): First Livestock Development Programme (FLDP) Staff Appraisal Report No 5795Uni 1985. West Africa Project Department, Agriculture Division B.

NIGERIA. (1985b): Second Livestock Development Programme Development of Grazing Reserve Resource and Socio-economic Survey, Bobi Grazing Reserve, Niger State. 32.

NIGERIA. (SLDP 1988): SLDP Project files Working Papers, Volumes I and II (SLDP 1986. West Africa Projects Agriculture Department (WAPAD).

NURU S.F. (1982): Problems and prospects of the Nigerian beef industry. In Osinowo A.O. et al (eds.): Beef Production in Nigeria. Pro. Nat. Conf. Beef. Prod. Nigeria. 12 -43.

OLUOKUN S.B. (1992): Prospective planning for livestock development in Nigeria: An overview. In Adawa D.A.Y. et al (Eds.). Book of proceedings of the scientific session, $29^{\text {th }}$ Annual General meeting of the Nigerian Veterinary Medical Association, Kaduna 1992. 186-191. (1992).

SULEMAN H. (1988): Policy issues in pastoral development. In Gefu et al (Eds.). Pastoralism in Nigeria: Past, Present and Future. 38-51.

USDA (2002); United States Department of Agriculture (USDA), Keeping America Free From Foreign Animal Diseases FAD Animal Health Emergency Management Training CD 